Portland State University

PDXScholar

8-18-1995

\title{
Shoot Structure of Boschniakia hookeri Walpers (Orobanchaceae)
}

John Leland Babur

Portland State University

Follow this and additional works at: https://pdxscholar.library.pdx.edu/open_access_etds

Part of the Biology Commons

Let us know how access to this document benefits you.

Recommended Citation

Babur, John Leland, "Shoot Structure of Boschniakia hookeri Walpers (Orobanchaceae)" (1995).

Dissertations and Theses. Paper 4931.

https://doi.org/10.15760/etd.6807

This Thesis is brought to you for free and open access. It has been accepted for inclusion in Dissertations and Theses by an authorized administrator of PDXScholar. Please contact us if we can make this document more accessible: pdxscholar@pdx.edu. 


\section{THESIS APPROUAL}

The abstract and thesis of John Leland Barbur for the Master of Science in Biology were presented August 18, 1995 and accepted by the thesis committee and the department.

COMMITTEE APPROUALS:

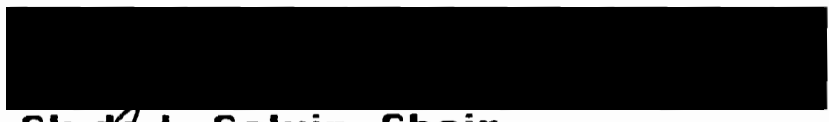

\section{Clydé L. Calvin, Chair}

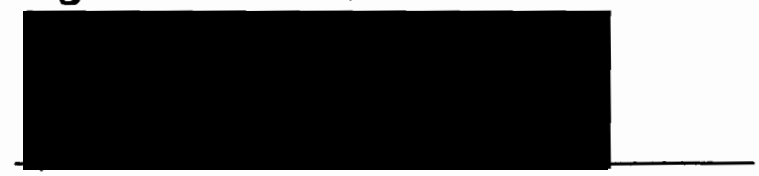

Robert 0. Tinnin

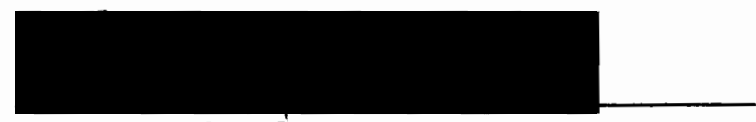

Richard Forbes

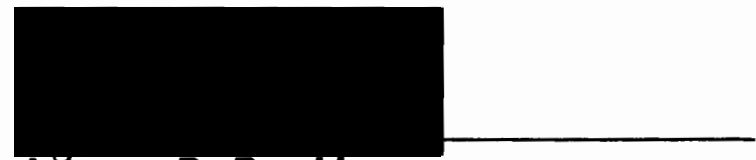

Jămes R. Pratt

Representative of the Dffice of Graduate Studies

DEPARTMENT APPROUAL:

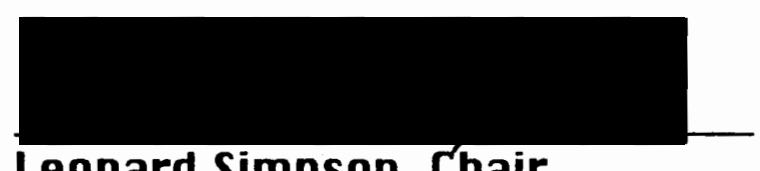

Leonard Simpson, Chair

Department of Biology

$* * * * * * * * * * * * * * * * * * * * * * * * * * * * * * * * * * * * * * * * * * * * * * * * * * * * * * * *$

ACCEPTED FOR PORTLAND STATE UNIUERSITY BY THE LIBRARY 
ABSTRACT

An abstract of the thesis of John Leland Barbur for the Master of Science in Biology: presented August 18, 1995.

Title: Shoot structure of Boschniakia hookeri Walpers (Orobanchaceae)

Boschniakia hookeri Walpers has been found to parasitize the roots of Gaultheria shallon Pursh, Arctostaphylos uva-ursi (L.) Spreng, and Daccinium ovatum Pursh, all members of the Ericaceae. This is the first documented report of the parasitism of Daccinium ouatum. The subterranean shoot of $\underline{B}$. hookeri originates endogenously from the perennial tubercle of the parasite. The shoot has an eustele, composed of collateral vascular bundles, arranged in four composite fronts 
and separated by four wide 'leaf gaps.' Pits on metaxylem vessels range from nearly circular to laterally elongated. All vessel members have simple perforations. Ouerall, the kylem of subterranean shoots contained relatively few tracheary elements. Phloem is abundant, with radial series of sieve tube members that have simple sieve plates. Brachysclereids forming large clusters are positioned to both the inside and outside of the vascular bundles. Abundant stomata are present and frequently raised above the shoot surface. firillary buds along subterranean shoots are capable of producing flowers or branch shoots. Considerable secondary growth occurs in maintained shoots below developing branch shoots. This manifested by the additional production of secondary kylem and phloem, and the formation of a protective cuticular epithelium. This study of $\underline{\text { B. hookeri }}$ supports the view that the short and fleshy character of the subterranean shoot, increased presence of phloem, reduction of leaves to scales, and a perennial nature are specializations associated with the holoparasitic mode of life. 
SHOOT STRUCTURE OF BOSCHNIAKIA HOOKERI WALPERS

(OROBANCHACERE)

by

JOHN LELAND BARBUR

A thesis submitted in partial fulfillment of the requirements for the degree of

MASTER OF SCIENCE

in

BIOLOGY

Portland State University

1996 
ACKNOULEDGEMENTS

I am grateful to the faculty in the Portland State University Biology Department for their instruction. As individuals, they exemplify the highest standard in research and teaching performance.

I would like foremost to thank Dr. Clyde L. Calvin for allowing me to conduct this investigation under his guidance. His knowledge of parasitic flowering plants provided the inspiration to study the root parasite, Boschniakia hookeri. His valuable time, laboratory materials and equipment were indispensable in the production of this thesis.

Several faculty members and student colleagues deserve special mention. Dr. Byron Lippert inspired me to pursue 
botany. Dr. Lester Newman aduised me to focus on one organism. I am grateful to Dr. Richard Forbes for repeating the encouraging refrain 'You're doing just fine', and to Dr. Robert Tinnin for instilling an approach to viewing ecological issues with unbiased and equally weighted thought. Carol Wilson provided helpful feedback and reference suggestions regarding morphological questions. John Moulton helped answer chemistry and computer-related questions, and Ralph Wells proofread this thesis and provided friendly support over many years. 
TABLE OF CONTENTS

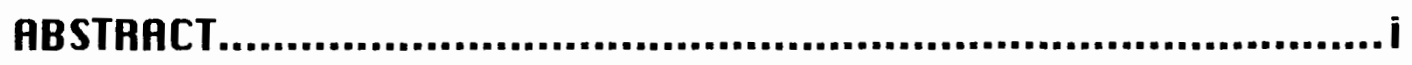

ACKNOWLEDGEMENTS...................................................... iii

TABLE OF CONTENTS............................................................ v

LIST OF FIGURES............................................................... vi

INTRODUCTION....................................................................... 1

MATERIALS AND METHODS...................................................... 9

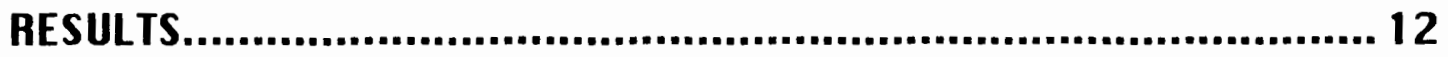

HOST SPECIFICITY........................................................ 12

TUBERCLE MORPHOLOGY............................................. 13

SUBTERRANEAN SHOOT GENERAL MORPHOLOGY.................... 14

ENDOGENOUS ORIGIN OF THE SHOOT................................ 16

SHOOT STRUCTURE......................................................... 17

Pith....................................................................... 18

Corteห.................................................................. 19

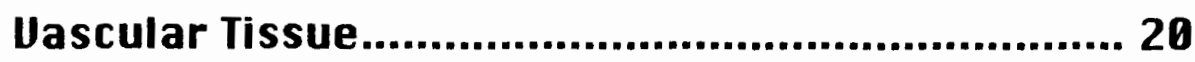

Epidermis............................................................... 23

SHOOT AND TUBERCLE INTERFACE.................................. 24

SCALE LEAUES........................................................ 25

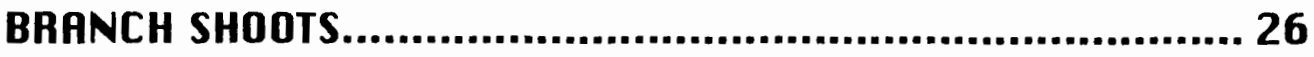

Secondary Growth............................................... 27

ADDITIONAL OBSERUATIONS........................................... 30

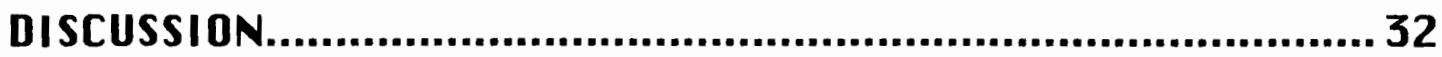

LITERATURE CITED..................................................................49 


\section{LIST OF FIGURES}

\section{FIGURE}

1. An inflorescence of Boschniakia hookeri with its tubular and bilabiate corolla was characteristic of both the Orobanchaceae and Scrophulariaceae.... 2

2. Development of the tubercle and subterranean shoot......................................................................... 14

3. An excauated specimen of B. hookeri.................... 15

4. Small tubercle in longitudinal section....................15

5. Portion of a shoot in transuerse section............... 18

6. A vascular bundle with collateral arrangement of conducting tissues............................................ 21

7. Longitudinal section of xylem..............................21

8. Sieve tube members with fluorescing callose on sieve plates and lateral pores............................... 23

9. Stoma with thickened guard cell walls................. 24

18. Exposure of a subterranean parasite. Inflorescence (shoot) death resulted in the activation of two branch shoots

11. Detail of Figure 10. Shoot death led to the activation of lateral shoots. Formation of corklike layer occurred at the juncture of branch shoot down to the tubercle interface................... 28

12. A transuerse section along a maintained shoot where cuticularized epithelium formed a corklike layer.

13. Uascular bundles of the maintained shoot in figure 12 
INTRODUCTION

More than three thousand species of parasitic angiosperms are recognized (Sauerborn 1991). Among these are parasites that form attachments with host roots to obtain their nutrients and water. Due to their subterranean habit, root parasites often remain hidden from the view of the unacquainted observer except for the appearance of an aerial inflorescence (Figure 1). Members of the Orobanchaceae (Broomrape family) are highly specialized parasites with close affinities to the Scrophulariaceae, the Figwort family (Boeshore 1920; Kuijt 1969; Metcalfe and Chalk 1950; Tiagi 1963; Weber 1987). Boeshore's (1920) study detailed a structural series of "degradation" from the hemiparasitic figworts through the holoparasitic broomrapes. Boeshore (1920) viewed the one substantial morphological difference between the two 


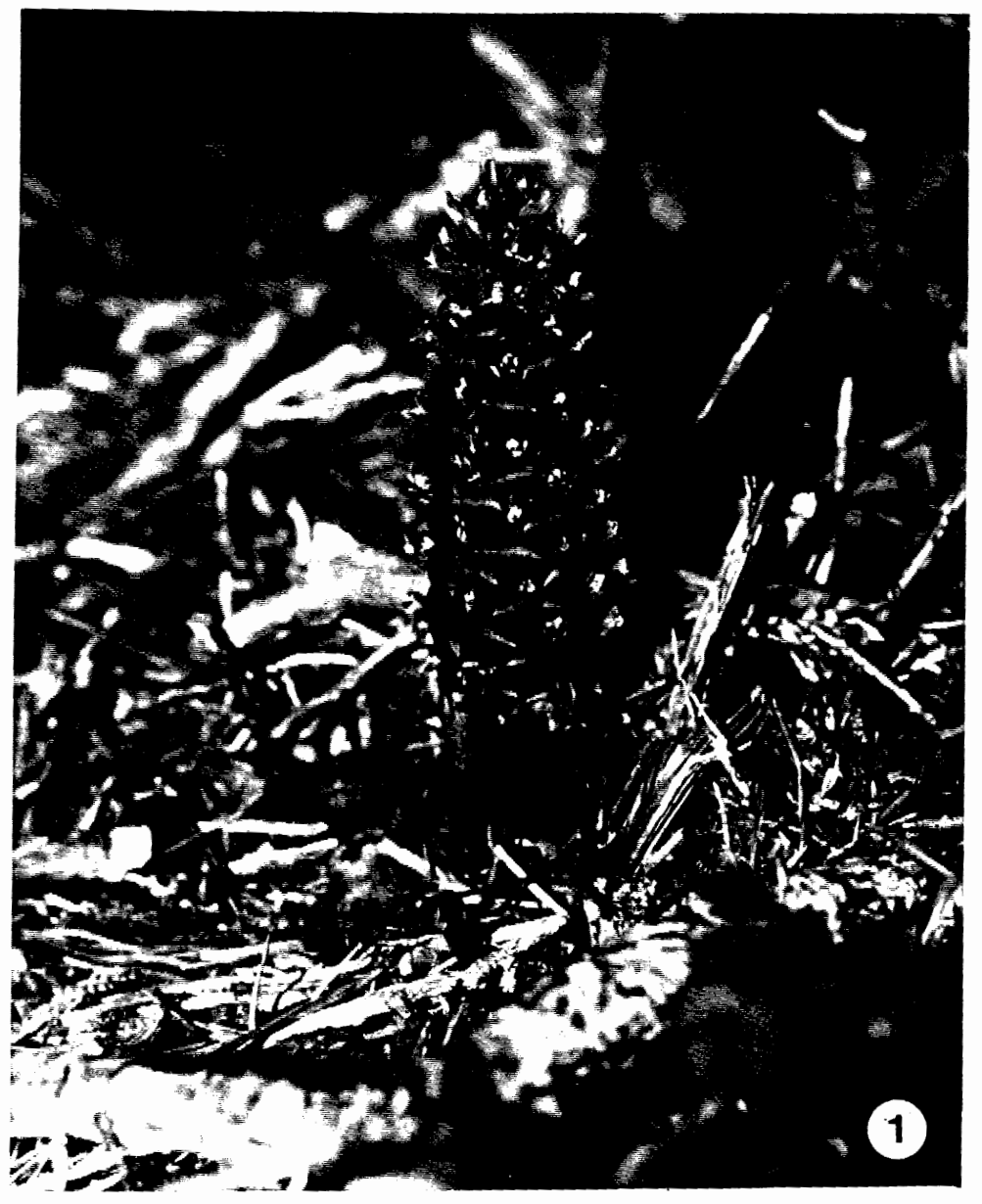

Figure 1. An inflorescence of Boschniakia hookeri, with the tubular and bilabiate corolla, characteristic of both the Orobanchaceae and Scrophulariaceae, $\mathrm{k1}$ / 2 .

families to be the two-celled ovary in the Scrophulariaceae and one-celled ovary in the Orobanchaceae. This continues to be a key morphological distinction for the classification of members of the Orobanchaceae (Gilkey 1980, Hitchcock et al. 1990, Munz 1963, Peck 1961). In addition, all broomrapes are considered to be devoid of chlorophyll, and hence are true holoparasites 
(Boeshore 1920, Gilkey 1980, Hitchcock et al. 1990, Metcalfe and Chalk 1956, Munz 1963, Peck 1961 ).

Boschniakia species (ground-cone) are root parasites in the Orobanchaceae. They are perennial, achlorophyllous, holoparasitic herbs parasitizing mostly members of the Ericaceae (Heath family). Their distribution is in the coastal scrub and closed-cone pine forests in the North Pacific realm. Boschniakia (Kylanche) himalaica occupies the westernmost extent of the range. According to Polunin and Stainton (1984), this species occurs from north India to southwest China, where it was described as parasitic on Bhododendron species. Three North American species of Boschniakia are currently recognized (Gilkey 1945). B. strobilacea occurs from Josephine County, Oregon, southward into the San Bernardino Mountains. Found inland, it parasitizes species of Arctostaphylos (manzanita) and Arbutus (madrone). B. rossica ranges from the Kuriles, Kamchatka, the Aleutians, and Kotzebue Sound southward to Sitka, and eastward to Great Slave Lake (Gariliuk 1965; Hultén 1968). It is reported to be parasitic only on Alnus crispa spp. sinuata, the Sitka alder (Gariliuk 1965; Gilkey 1945; Hultén 
1968). This presents an interesting exception to the hostspecificity of Boschniakia species to members of the Heath family. The subject of this study, Boschniakia hookeri, has a coastal distribution from Uancouver Island southward to northern California. Floras of the western United States (Gilkey 1945, 1980; Hitchcock et al. 1990; Munz 1963; Weidemann et al. 1974 ) list the host of B. hookeri exclusively as salal (Gaultheria shallon) or as various ericaceous plants (Peck 1961). Identification of a host is often difficult because roots become extensively intertwined, or they may immediately grow downward, becoming untraceable. Mistakenly, hosts are often considered to be the closest member of the Heath family to the parasite. For esample, Gilkey $(1945$, p. 10) wrote, “...a specimen of Boschniakia was found surrounded by two species of Arctostaphylos and two of Daccinium, with no other genera in sight. Our earlier conclusion [Gaultheria being the only host] appeared in this case to break down until the writer followed the attached root several feet across the trail and under the roots of other plants, finally coming to its source--a Gaultheria plant not more than a foot high, completely ouer-shadowed by a manzanita."

Olsen and Olsen (1981) were successful in artificially 
stimulating parasitism by $\underline{B}$. hookeri on salal (Gaultheria shallon), kinnikinnick (Arctostaphylos uva-ursi) and Pacific madrone (Arbutus menziesii). Howeuer, positive host identification in nature can only occur when a parasite is collected on a host root traced to the recognizable aerial plant.

Few studies have focused on the biology of Boschniakia species. A thorough taxonomic review on $\underline{B}$. hookeri commenced with Gilkey's (1945) monograph Boschniakia in Western United States. Her work substantially elucidated the floral and vegetative morphology of this species. Kuijt's (1969) publication on the biology of parasitic plants reviews and illustrates $\underline{B}$. hookeri's floral, seed coat and leaf structure in a chapter on the broomrapes. It has been determined that an anthomyiid fly, Pegomya hyperparasitica, parasitizes $\underline{B}$. hookeri (Deyrup 1989; Olsen, Deyrup, and Deyrup-0Isen 1989). The fly lays its eggs in the flowers of $\underline{B}$. hookeri. Its larvae then feed on the ovaries and fleshy inflorescence of the parasitic plant. Other studies have investigated unique chemical constituents found in Boschniakia species (Murai and Tagawa 1980, Sisido et al. 1967, Tsuda et al. 1994, Tusda et al. 
1994). A brief overview of the biology of $\underline{B}$. rossica was given by Gariliuk (1965). Gariliuk covered the Soviet distribution of this species, characteristics of its seeds, and brief anatomical observations of the shoot.

Studies on the structure of broomrapes, including Boschniakia, are limited. Tiagi (1963) esamined the development of the male and female gametophytes of $\underline{B}$. himalaica. Olsen and Deyrup-Olsen (1979) and Olsen and Olsen (1980, 1981) determined that the host root, principally Gaultheria shallon, seeks out the seed of $\underline{B}$. hookeri by yetunknown cues. The investigators document that a primary haustorium becomes established immediately behind the host root-cap. The development of the perennial parasitic body is also described by Olsen and Olsen (1981). In Boschniakia this perennial, parasitic body has been described in the following terms: tubercle (Boeshore 1920; Kuijt 1969; Kuijt and Toth 1985; Metcalfe and Chalk 1950); nodule (Perciual 1931); corm (Gilkey 1945); and soma (Olsen and Olsen 1981). All are general botanical terms for describing the leafless haustorialcontaining, shoot-producing portion of the broomrapes. I will 
refer to this body as the tubercle, a "swollen stem-like organ" (Kuijt and Toth 1985). In addition, the subterranean portion of the flowering stalk will be identified as the subterranean shoot.

The haustorial interface of $\underline{B}$. hookeri has received the most focused anatomical attention. Kuijt and Toth (1985) found that vessel members and parenchyma formed connections to the host root xylem. Sieve tube members were not observed by Kuijt and Toth (1985) at the interface, nor were they discerned by Olsen and Olsen's (1981) examination of the perennial parasitic body. Sieve tube members have been identified in phloem at the haustorial interface in Orobanche (Dörr and Kollman 1975).

Investigations of aerial shoot structure in broomrapes have included B. rossica (Gariliuk 1965), Christisonia (Worsdell 1895), Epiphegus (Cooke and Schively 1904) or Epifagus (Walsh and Popouich 1977), and Orobanche (Beck 1930; Tate 1925) species. The shoots of these broomrapes have been generally characterized as having a single ring of vascular bundles, abundant phloem, sclereids in the ground tissues, reduced 
numbers of stomata, scale leaves with mesophyll not differentiated into spongy and palisade parenchyma, and greater development of phloem than sylem (Boeshore 1920; Metcalfe and Chalk 1950; Solereder 1908). Sieve tube members have been identified in Christisonia (Worsdell 1895), Epifagus (Walsh and Popovich 1977), and Orobanche (Beck 1930; Tate 1925) species. In contrast, the structure of the "basal section of the flowering shoot," presumably subterranean, was examined in Conopholis americana by Perciual (1931). It contained three rings of vascular bundles and only parenchymatous cells in the phloem.

This investigation of Boschniakia hookeri was designed with three primary goals in mind: 1) To determine host species; 2) to examine the general morphology of the tubercle and subterranean shoot; and 3) to determine the structure of the subterranean shoot. 
MATERIALS AND METHODS

Specimens of Boschniakia hookeri Walpers were collected near Happy Camp, Tillamook County, Oregon (Section 31 of T1S, R10w) in March and May, 1994, and March and May, 1995. Collection consisted of the host root, parasite tubercle and shoot, when present. Specimens with positively identified hosts Uaccinium ouatum Pursh [HPSU\# 6219, 6220] and Gaultheria shallon Pursh [HPSU\# 6223, 6224] were collected and subsequently deposited in the Portland State University Herbarium. A single collection on the host Arctostaphylos uvaursi (L.) Spreng. remains in my personal collection [94-1]. Specimens were photographed in the field using a Pentar K $100035 \mathrm{~mm}$ camera with a $50 \mathrm{~mm}$ and macro lens on Fujichrome 100 film.

Specimens for anatomical study were cleansed of soil by 
a shower of water and gentle scrubbing with a camel hair brush, preserved in formalin-propionic acid-alcohol, dehydrated in tertiary butyl alcohol and embedded in Paraplast+ (Jensen 1962). Sectioning of paraffin-embedded specimens was performed on an $\mathrm{hO}$ Spencer 820 Microtome. All sections were cut at $12 \mu \mathrm{m}$ thickness. Paraffin sections were fastened to glass microscope slides by a $4 \%$ formalin float and Haupt's adhesive (Jensen 1962).

For brightfield microscopy, sections were stained with safranin-fast green (Jensen 1962) with the following modification--Hemosol was substituted for the toxic solvent kylene throughout the stain series. Staining in safranin was extended to 2-4 days. Fast green staining time was increased to 60 seconds. All photomicrographs were taken with a Zeiss Standard Universal Microscope. Kodak Ectachrome 64T film and Tri-K Pan 485 inch sheet film were used for photography of stained sections.

For identification of callose, sections were stained with aniline blue and viewed with fluorescence microscopy (Currier and Strugger 1955; Eschrich and Currier 1964). Fluorescence 
microscopy employed barrier filters 47 plus 53 and exciter filters BG12 plus BG38. Kodak Tri-K Pan 35mm print film was used for fluorescence photography.

Additional methods were also employed in this study. Phloroglucin $\mathrm{HCl}$ was used for identification of lignified cell walls in free-hand sections of preserved specimens. Iodine potassium iodide $\left(\mathrm{I}_{2} \mathrm{KI}\right)$ was utilized for resolution of starch distribution and polarized light was used to ascertain the presence and distribution of crystals. 
RESULTS

\section{HOST SPECIFICITY}

The collection site for this study was in a Picea sitchensis (Sitka spruce) and Pinus contorta (shore pine) dune forest, the understory dominated by ericaceous shrubs. Boschniakia hookeri was found parasitizing mainly Gaultheria shallon, a widely scattered shrub at the site. A single specimen of the parasite was collected on Arctostaphylos uva-ursi. This host grew primarily in a highly esposed strip between a road and the dune forest. Of interest, $\underline{B}$. hookeri was also found parasitizing Uaccinium ovatum on several occasions, the most common shrub at the collection site. Untraceable specimens for anatomical or morphological esamination were likely parasitizing Gaultheria based on bark characteristics. The bark of Gaultheria is identifiable as dark and smooth, unlike the bark 
of Arctostaphylos and Waccinium.

TUBERCLE MORPHOLOGY

Parasite tubercles ranging from $2 \mathrm{~mm}$ to $35 \mathrm{~mm}$ in diameter were found on host roots (Figure 2). The approsimate minimum tubercle size for shoot emergence was $10 \mathrm{~mm}$. Tubercles generally had a spherical shape, although they flattened along the haustorial interface. Shoots consistently arose from the tubercle's upper hemisphere, opposite the lower, haustorial-containing hemisphere. The first sign of the emergence of a shoot was seen as a disruption in the regular checkering of the cork-like tubercle surface. In small tubercles the upper hemisphere often became distorted by the eruption of shoots (Figure 2). Tubercles ouer $20 \mathrm{~mm}$ often had shoot abscission scars on their upper hemisphere (Figure 2). Shoots emerging from the tubercle manifested a negative gravitropic response, growing toward the soil surface (Figures 2 and 3). 


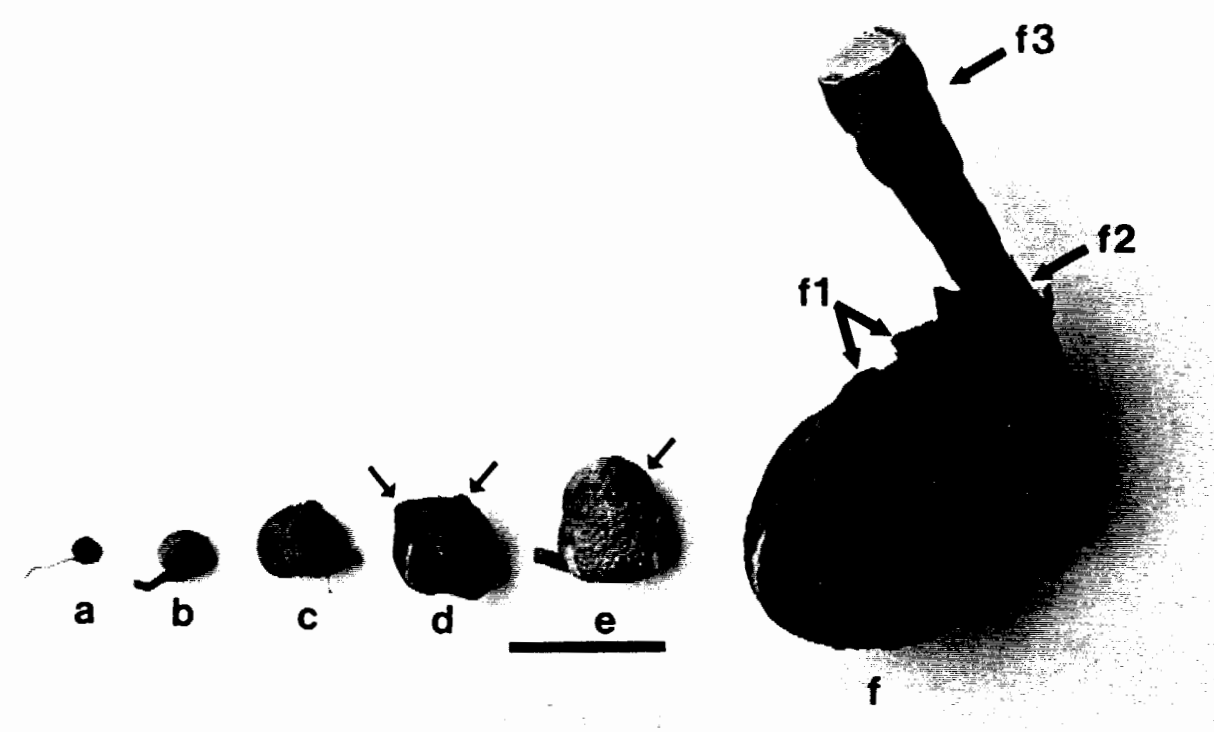

Figure 2. Development of the tubercle and subterranean shoot: $a, b$ and $c$, the development of the spherical tubercle; $d$, two subterranean shoots distorting the cork-like tubercle surface at the upper hemisphere; e, subterranean shoot erupting from a small tubercle; f, large tubercle with shoot abscission scars ( $f 1$ ), decayed shoot $(f 2)$ and new shoot ( $f 3$ ) displaying negative gravitropism. Bar $=20 \mathrm{~mm}$.

SUBTERRANEAN SHOOT GENERAL MORPHOLOGY

B. hookeri generally became established in the first several centimeters of a sandy loam covered by a thick layer of organic material. Subterranean shoots were found as 

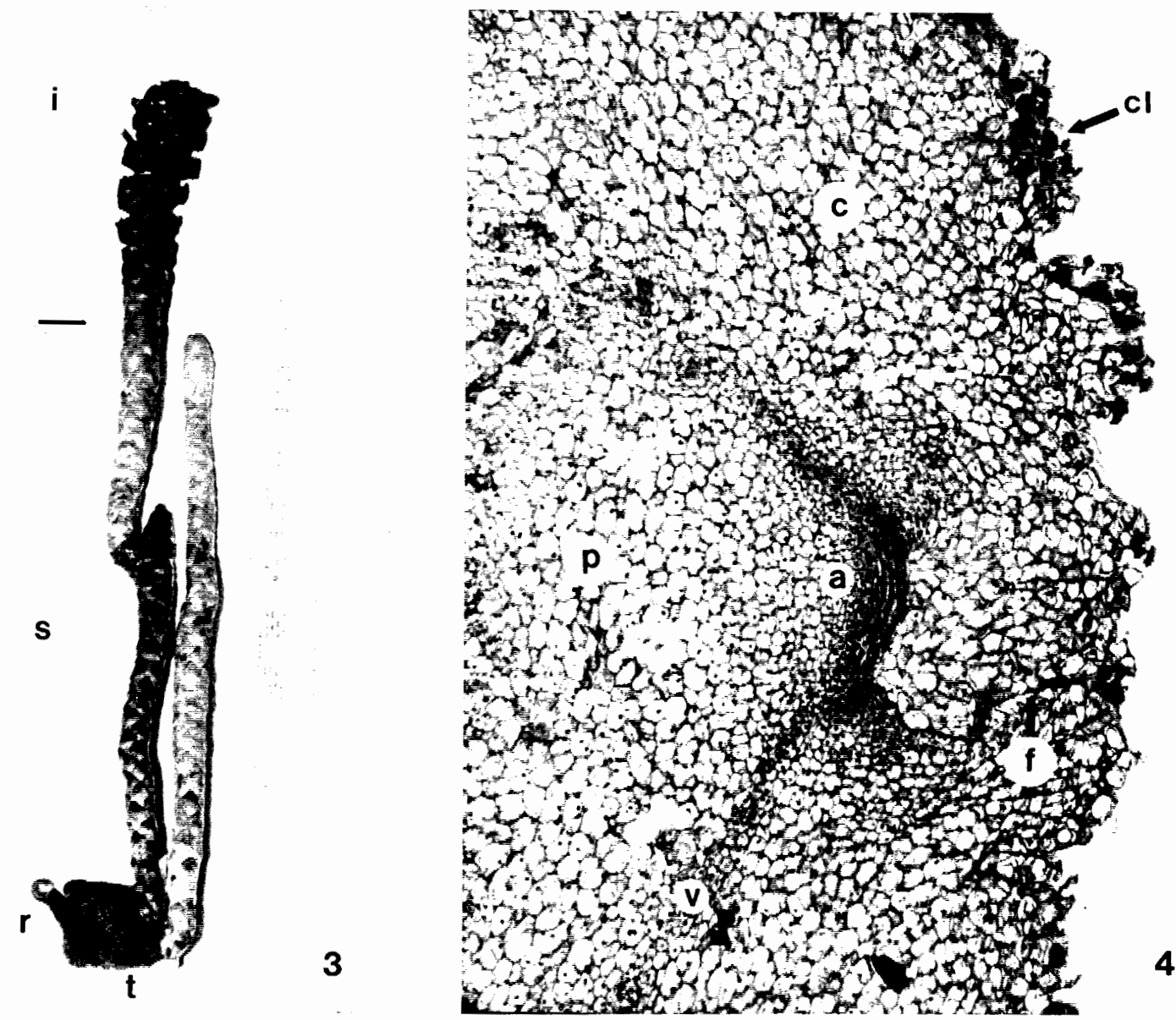

Figure 3. An excavated specimen of $\underline{B}$. hookeri: $r$, host root; $t$, parasite tubercle; $s$, shoots $(25 \mathrm{~cm}$ length) exhibiting negative grauitropism at tubercle interface; $i$, inflorescence, $\mathrm{H} 1 / 4$. Figure 4. Small tubercle in longitudinal section: a, shoot apex; c, corter; cl, cork-like cells; f, radially-orientated fissure; $v$, tubercle vascular tissue; $p$, pith-like region; $\mathbf{~} 40$.

short as $1 \mathrm{~cm}$, and as long as $25 \mathrm{~cm}$ in deeply established parasites (Figure 3). Subterranean shoots were pale yellow with alternately arranged leaves. Some deeply buried subterranean shoots had regions of more densely clustered leaues, possibly reflecting the end of a season's growth. This 
suggests that it may take more than one season for shoots to reach the surface of the organic layer.

Subterranean shoots typically had an obconical shape, i.e., a shoot narrowed from its арея to its base, where it merged with the tubercle (Figure 3). At the point of esit, scale leaves were the smallest, and limited internodal elongation resulted in considerable overlap in the leaves. Each scale leaf subtended an asillary bud. Two types of asillary buds, reproductive and vegetative, were observed in dissections or microscopic esaminations. The upper shoot region, while apparently still subterranean, had scale leaves subtending floral buds. Floral buds could be identified by the presence of two elongated bractlets. Axillary buds on lower shoot regions were vegetative, giving rise to branch shoots.

\section{ENDOGENOUS ORIGIN OF THE SHOOT}

Sections of small tubercles (4-5mm) with no external euidence of shoot emergence revealed an endogenous origin of subterranean shoots (Figure 4). A shoot арея originated in the 
tubercle's cortex. In one tubercle more than one shoot primordium was developing. The apices were often flanked by leaf primordia. Cortical cells peripheral to the shoot apes were enlarged and deuoid of starch, and the tissue developed radially-orientated fissures prior to growth of the shoot through the tubercle (Figure 4).

\section{SHOOT STRUCTURE}

Subterranean shoots selected for structural study were 6 to $8 \mathrm{~cm}$ in length, from tubercle to shoot арек. Samples approsimately $3 \mathrm{~cm}$ aboue the tubercle interface were selected to characterize the shoot. At this level the shoot was at or near the end of primary growth. Gross anatomy of the shoot was a eustele of collateral bundles, the bundles containing phloem to the outside and rylem to the inside (Figure 5). There were four composite bundle fronts that gave the appearance of a square or quadrangle, rather than a ring of vascular tissue. Four broad 'leaf gaps' separated the vascular bundle fronts. The bulk of the shoot was composed of the ground tissue of the 


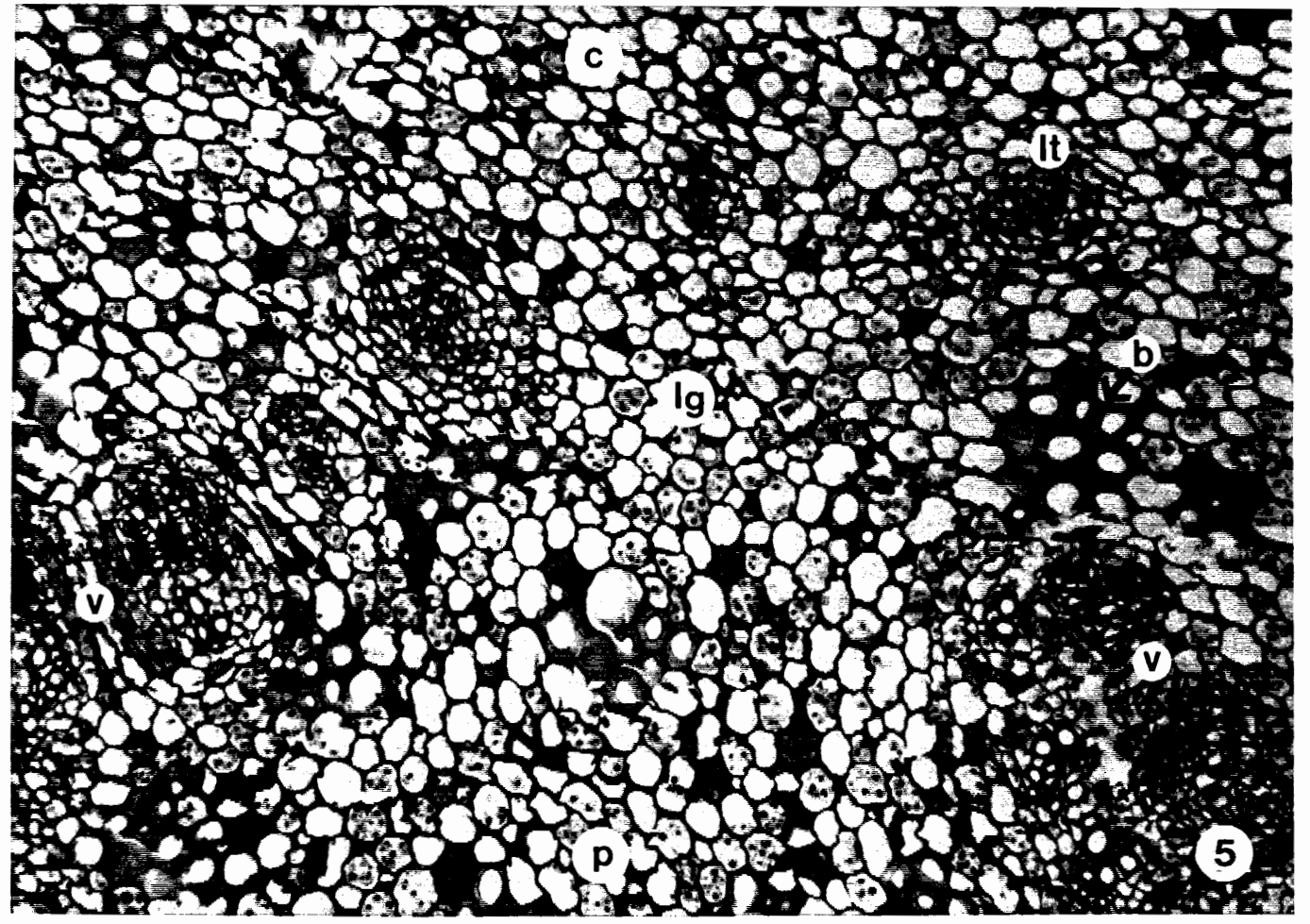

Figure 5. Portion of a shoot in transuerse section: c, cortex; p, pith; b, clusters of brachysclereids; Ig, leaf gap; It, leaf trace; $v$, vascular bundle fronts, $\mathbf{k 4 0}$.

corter and pith.

Pith

Two cell types were recognized in the pith. The majority of the pith was composed of large storage parenchyma (Figure 5). In longitudinal section the parenchyma cells were twice as long as their transuerse section width. Starch grains, most 
compound, were located in the prosimal region of these cells. Druse crystals of 4-5 $\mu \mathrm{m}$ diameter were found infrequently within parenchyma cells. Intercellular air spaces in the ground parenchyma were large and ubiquitous. Brachysclereids (stone cells) were abundant in the pith. Sclereids most often formed clusters, the largest of which were positioned just inside the vascular bundles. Sclereids in longitudinal section had truncated to slightly oblique end walls and lacked intrusive growth. Sclereids had simple, often branched pits and most were living at maturity as indicated by prominent nuclei.

\section{Cortes}

Parenchyma cells and brachysclereids were also present in the cortex (Figure 5). Cortial parenchyma was similar to that found in the pith in shape and starch content, although starch accumulation was greatest in the inner cortex and decreased toward the outer corter. Druse crystals were present in parenchyma cells and in greater abundance than in the pith. Cortial brachysclereid clusters were more abundant than in the 
pith, forming in greatest concentration immediately outside of the vascular bundles and in leaf gaps (Figure 5). In the outer cortek, sclereid clusters were smaller, and isolated sclereids were more frequent.

Vascular Tissue

Parenchyma cells composed most of the sylem (Figure 6). Tracheary elements were distributed irregularly among the xylem parenchyma (Figure 6). Protoxylem elements contained some annular, but mostly helical thickenings (Figure 7). Metaxylem contained vessel members with scalariform or reticulate thickenings, or bordered pits (Figure 7). Lateral wall pit apertures ranged from nearly circular to strongly elongated (Figure 7). All vessel members had simple perforations.

Phloem was abundant in the shoot. Parenchyma cells and sieve tube members were both present (Figure 6). Parenchyma cells often formed radial series and contained very little starch. Sieve tube members were also arranged in conspicuous radial series (Figure 6). Sieve tube members were readily 

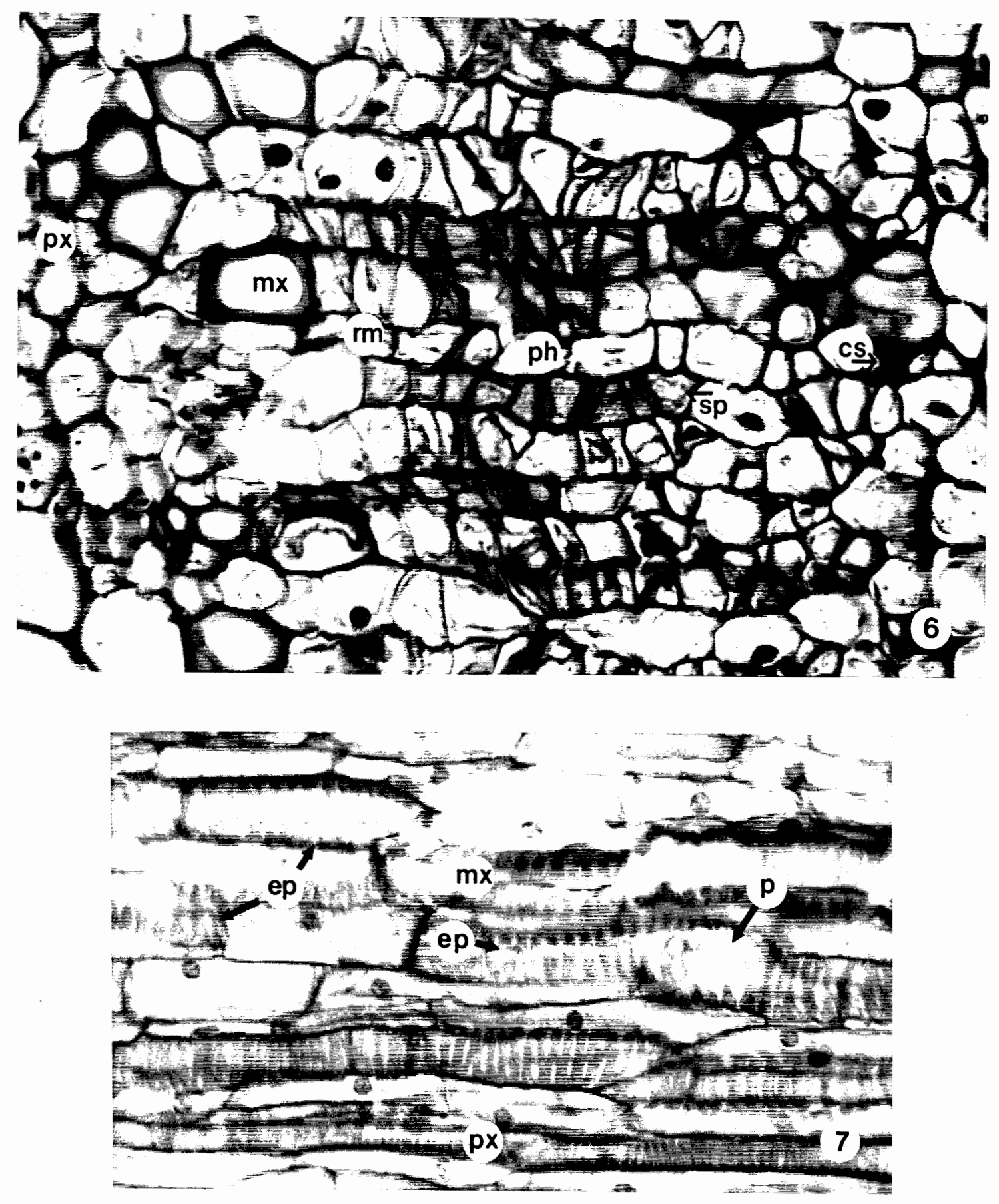

Figure 6. A vascular bundle with collateral arrangement of conducting tissues: px, protoxylem; ms, metaxylem; rm, residual meristem; ph, phloem; sp, simple sieve plate and pores; cs, collapsed sieve tube members, 4250 . Figure 7. Longitudinal section of kylem: pк, protosylem; mк, metaxylem; ep, elongate pitting; p, simple perforation, $\mathbf{2 5 0 .}$ 
identified due to their intensely stained nacreous walls (Figure 6). Sieve tube members had nearly transuerse, simple sieve plates, with sieve plate pores readily observed in transuerse sections (Figure 6). Fluorescence microscopy and aniline blue stain, a positive test for callose, showed callose deposited on sieve plate pores, and dispersed lateral pores on sieve tube members (Figure 8). Some sieve tube members in longitudinal section had a red-stained plug at the sieve plate, interpreted to be a P-protein or slime plug. Collapsed sieve tube members were common in the nonconducting phloem (Figure 6).

Vascular bundles nearing the end of primary growth had undifferentiated cells located between the sylem and phloem (Figure 6). This residual meristematic tissue contributed to the formation of the fascicular cambium. Meristemetic cell walls were thin and frequently torn in transuerse sections. Meristematic cell walls were stained a uniform light green in longitudinal section, distinctive from all other cells in the shoot. Each meristematic cell contained a pronounced nucleus with several euident nucleoli. 


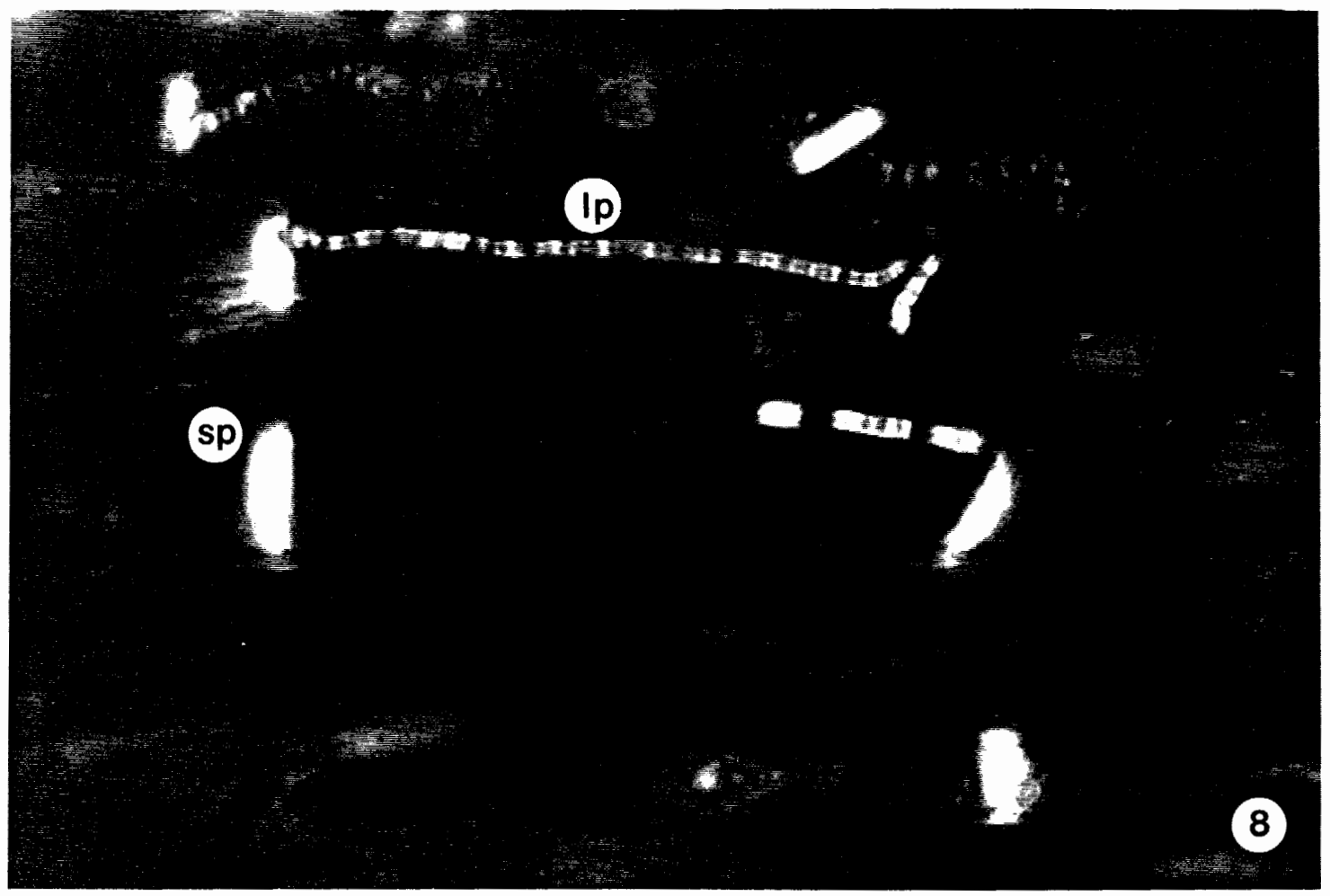

Figure 8. Sieve tube members with fluorescing callose on sieve plates and lateral pores: sp, sieve plate; Ip, lateral pores, $\mathbf{8 4 0 0 .}$

\section{Epidermis}

The cells of the epidermis were nearly circular in transuerse section (Figure 9). The outer, exposed wall, was covered by a thick cuticle with ridges oriented with the vertical axis of the shoot. Stomata on the stem were most abundant in the regions covered by scale leaves (Figure 9). The stomatal comples appeared to be the anomocytic type and were often raised above the surface of the stem. Some 


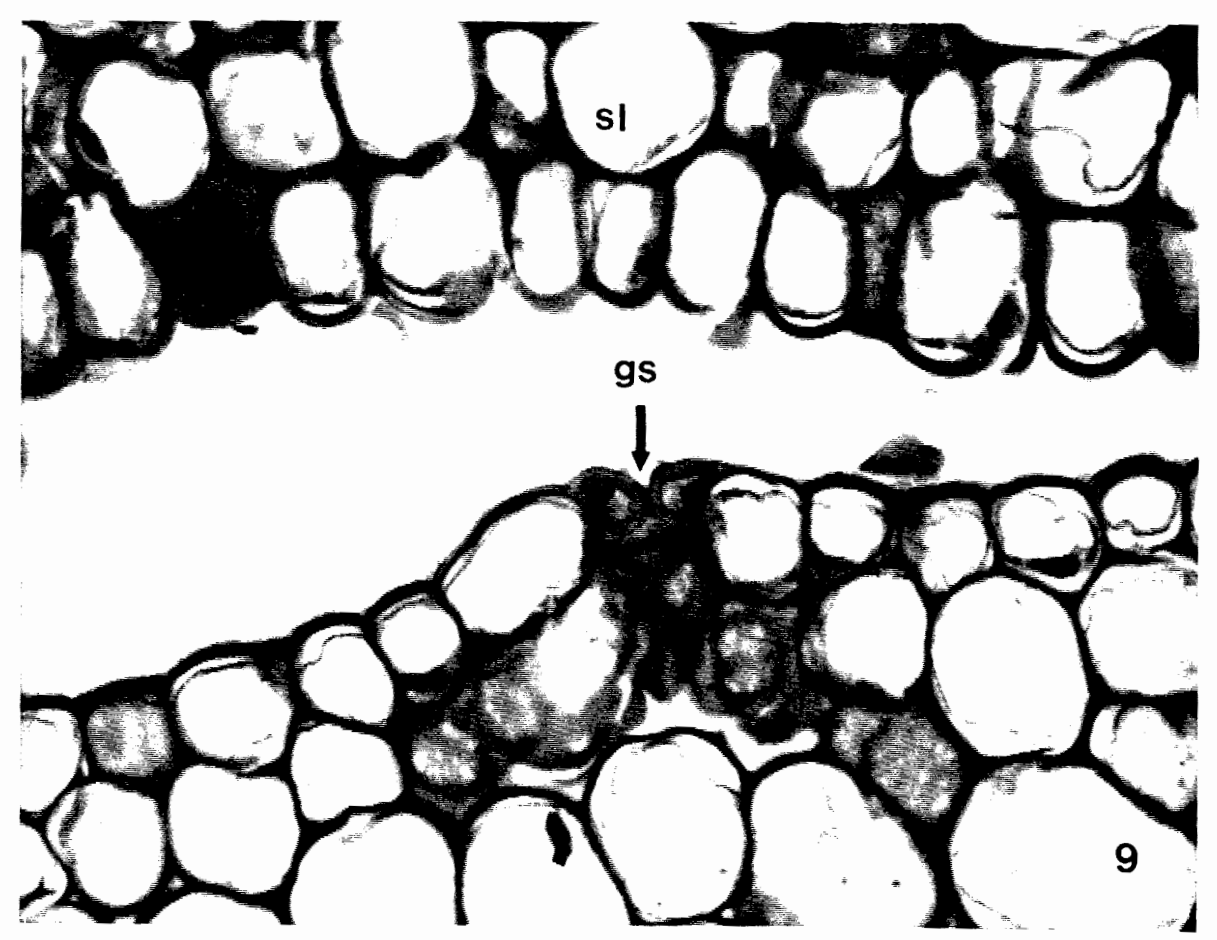

Figure 9. Transuerse section of raised stoma with thickened guard cell walls: gs, guard cells; sl, scale leaf, 4250.

enclosed a cuticle-lined crypt. Guard cells usually developed thickened walls that readily stained by safranin, though not by phloroglucin $\mathrm{HCl}$.

\section{SHOOT AND TUBERCLE INTERFACE}

Transuerse sections of a shoot at the interface with the tubercle exhibited changes from the structure characterized above. In contrast, stomata along the stem interface lacked 
thickened walls and appeared fully functional. Twelve to fourteen large, evenly spaced collateral bundles formed a ring of uascular tissue. Brachysclereid clusters became more abundant in the cortex and medullary rays. At the level of shoot emergence pith parenchyma became smaller and irregularly shaped and the ground tissue of the shoot and tubercle became confluent. Below the shoot origin, the tubercle maintained a 'pith' with collateral bundles.

\section{SCALE LEAUES}

Examination of scale leaves was not a primary focus of this study. However, the following were observations made during the examination of the subterranean shoot.

Exposure of a subterranean shoot (figure 10) revealed that vegetative leaves were reduced to scales (Figure 11). The decurrent leaf bases were principally responsible for the fourlobed shape in transuerse sections of the shoot. Each lobe was adjacent to one of the four broad leaf gaps. Leaf traces departing a dicotyledonous eustele do not have a 'gap,' in the 
same sense as is seen in ferns (Gifford and Foster 1989).

However, 'leaf gaps' were consistently identified that contained three leaf trace bundles (Figure 5) representing a three trace, unilacunar node. As the leaf traces extended through the cortes they divided, forming additional bundles. At their widest portion, scale leaf blades contained twelve to fourteen collateral vascular bundles of relatively uniform size. Mesophyll was not differentiated into palisade and spongy parenchyma. Further, close packing of parenchyma left limited intercellular spaces. Stomata were located primarily on those portions of the decurrent leaf bases that were covered by overlapping leaves. Like the stem, scale leaves were covered by a thick cuticle with vertically orientated striations.

\section{BRANCH SHOOTS}

After an inflorescence sets fruit, the shoot withers, dies, and eventually abscises from the tubercle (Figure 2). In deeply buried shoots, tubercles were found where a prior year's inflorescence had died back to about midway along the 
subterranean shoot (Figure 10). Along the maintained shoot branch (renewal) shoots developed; a feature characteristic of sympodial growth (Figure 10 and 11). A branch shoot then produced an inflorescence in a subsequent year (Figure 10).

Secondary Growth

The maintained subterranean shoot below asillary bud activation developed a cork-like layer (Figure 12). No organized cork cambium was found, however cortial cell divisions and wall cuticularization was evident immediately inside the cork-like layer. Cork-like cells contained dark stained material and appeared necrotic. A similar development of the cork-like layer was observed in small tubercles (Figure 4).

Secondary growth also occurred within the vascular bundles. Uessel members were dispersed among considerable sylem parenchyma (Figure 13). Further, a substantial amount of secondary phloem was present in the enlarged blocks of vascular tissue (Figure 13). Collapsed sieve tube members 

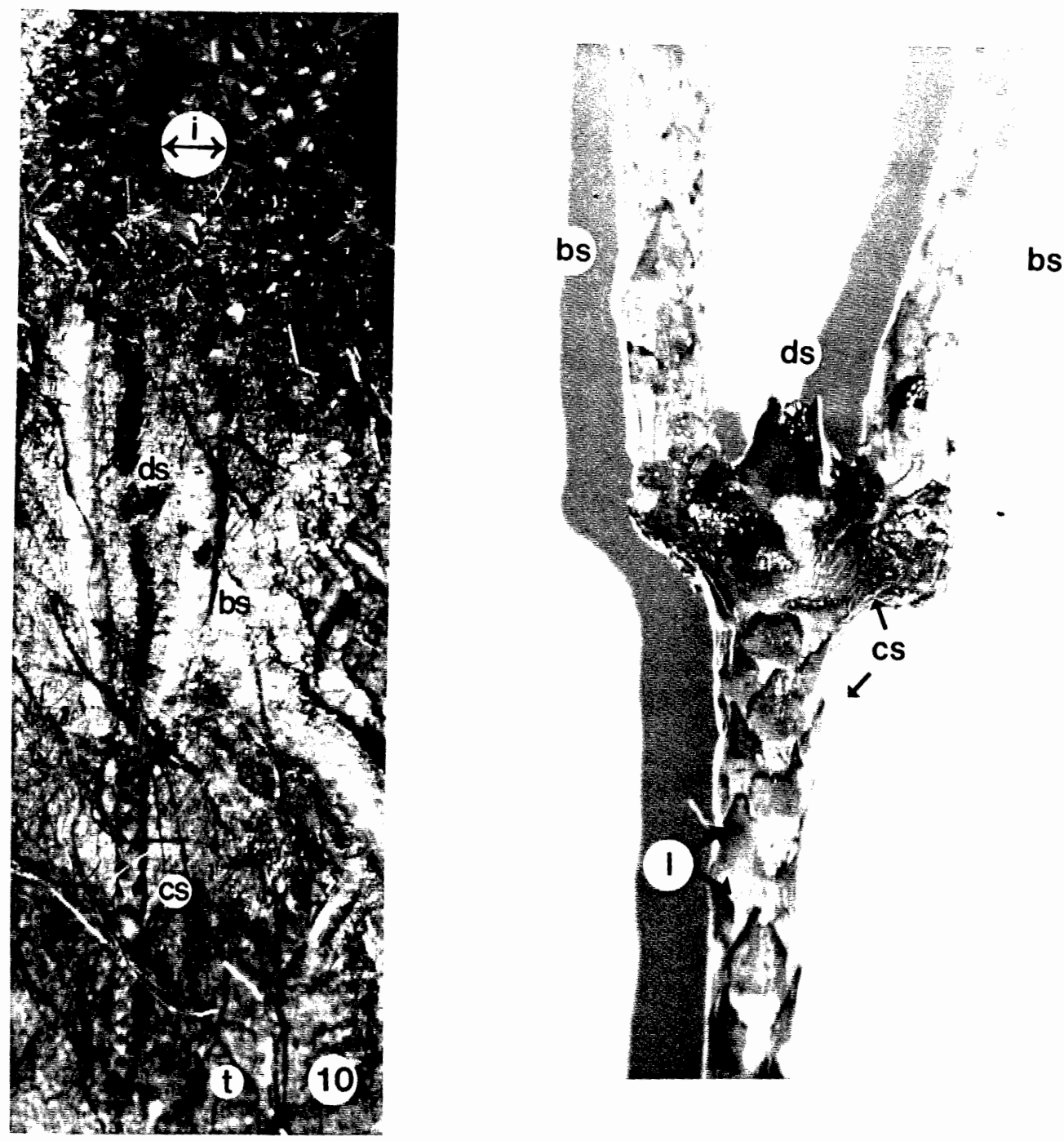

Figure 10. Exposure of a subterranean parasite. Inflorescence (shoot) death resulted in the activation of two branch shoots: $t$, tubercle; cs, cork-like covered shoot; bs, branch shoots; ds, dead shoot; $i$, inflorescence, $\mathrm{K} 1 / 3$.

Figure 11. Detail of Figure 10. Shoot death led to the activation of lateral shoots. Formation of cork-like layer occurred at the juncture of branch shoot down to the tubercle interface (not shown): I, thin upper leaf demarcated from lighter decussate base; ds, dead shoot; cs, cork-like covered shoot; bs, branch shoots, K1.5. 

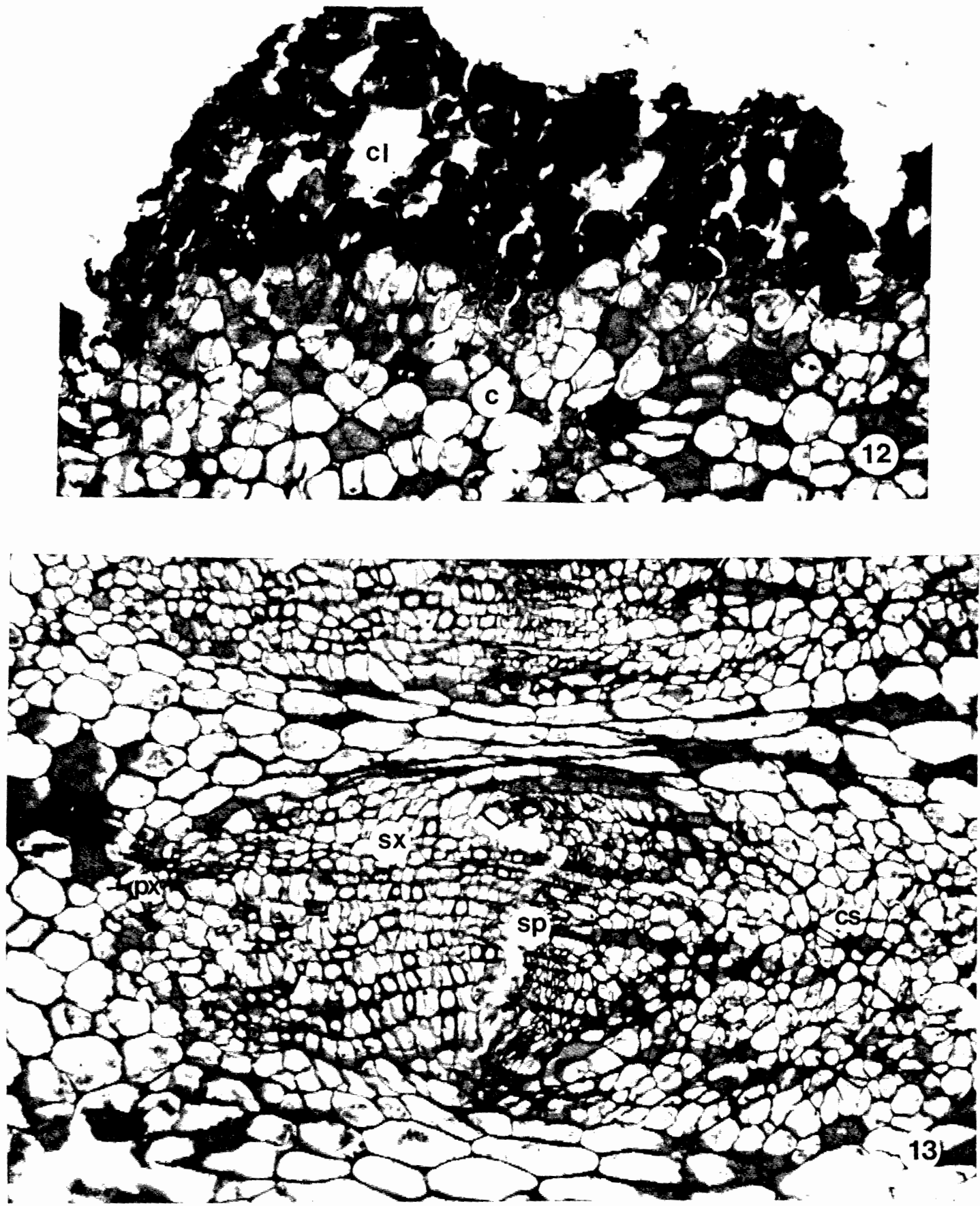

Figure 12. A transuerse section along a maintained shoot where cuticularized epithelium formed a cork-like layer: $c$, corter; cl, cork-like cells, $\mathrm{K} 100$.

Figure 13. Uascular bundles of the maintained shoot in figure 12: рк, protoxylem; sk, secondary kylem; sp, secondary phloem; cs, collapsed sieve tube members, $\mathbf{H 4 0}$. 
were common. Phloem fibers were not observed.

Interfascicular parenchyma became elongated and some

divisions occurred. However, divisions characteristic of an organized interfascicular cambium were not observed.

ADDITIONAL OBSERUATIONS

Wound areas were observed on scale leaves and subterranean shoots by visual and microscopic examination. Cortial parenchyma divided, suberized and lignified below the necrosed cells.

Fungal hyphae were frequently encountered. The hyphae seemed to locate preferentially between epidermal cells in the leaf asils and in wound areas.

Lastly, it was common to find larvae, presumably of a fly, attempting to exit specimens which had been placed into the preservative. On robust shoots, severe tissue damage to the cortes could be observed with the naked eye. Infrequent evidence of feeding also occurred in the pith. On one occasion, a weakened subterranean shoot broke from the tubercle and a 
Iarua was present at the interface. 


\section{DISCUSSION}

The Scrophulariaceae is a large family of mainly herbs and shrubs. Twenty-sik (Kuijt 1969) to thirty-seven (Musselman 1975) figwort genera have been documented with members manifesting various degrees of parasitism, including the hemiparasitic annuals Striga and Euphrasia and the perennials Castilleja and Pedicularis. The trends toward the holoparsitic mode of life account for the variable interpretation of the number of Scrophulariaceae and Orobanchaceae genera. According to Boeshore (1920) and Kuijt (1969), initial characteristics in the advancement to holoparasitism are the development of a shortened axis and fleshy stem. This "condensation" and fleshy structure is seen in the holoparasitic figworts Harveya and Hyobanche (Boeshore 1920). The fleshy, condensed axis, and one-celled ovary are consistent characteristics for all the holoparasites in the Orobanchaceae, 
including Boschniakia.

Development of a perennial structure has also been proposed as an advanced state in the holoparasites (Boeshore 1920). With the perennial structure, maintenance of parasitism on a perennial host is possible (Boeshore 1920). Further, Boeshore (1920) concluded that a perennial parasite favored selection for host-specificity. The aduanced holoparasitic broomrapes are exemplified by the monotypic genus Epifagus which parasitizes only members of the genus Fagus (Cooke and Schively 1904; Walsh and Popouich 1977), Conopholis which parasitizes members of the genus Quercus (Boeshore 1920, Perciual 1931), and Boschniakia hookeri which parasitizes only perennial genera of the Ericaceae. This study confirms that $\underline{B}$. hookeri parasitizes the ericaceous species Gaultheria shallon, Arctostaphylos uva-ursi, and it provides the first record of the parasitism of Vaccinium ovatum (evergreen blueberry).

The perennial tubercle of $\underline{B}$. hookeri is a highly specialized structure serving three functions. First, the tubercle contains the haustorial connection providing a physiological and structural bridge between parasite and host. Second, the 
tubercle is the principle perenniating body and is well endowed with vascular tissue. Third, within the tubercle arise shoots which terminate in an inflorescence.

Plant structures may originate in superficial tissue (exogenous) or from a more deep-seated tissue (endogenous). My study found that shoots of $\underline{B}$. hookeri arise endogenously-from the inner cortex of the tubercle. All subterranean shoots observed were initiated and developed in the tubercle's upper hemisphere. Endogenous shoot origin also has been observed in other broomrapes, for example Orobanche hederae (Kuijt 1969; Tate 1925) and several species of Christisonia (Worsdell 1895).

Parenchyma cells in the pith and cortes in $\underline{B}$. hookeri make up the largest volume of the subterranean shoot. Considerable intercellular space between parenchyma cells, especially in the pith, may provide a means for gas exchange in the shoot. This stands in contrast to the large lacunae reported as present in the cortex (Chatin 1856; Solereder 1908) and pith (Gariliuk 1965) of B. rossica.

Ground parenchyma in the shoot serves a principle role in 
storage. The most striking feature of the cortes and pith was the ubiquitous presence of starch, "the most common ergastic substance" (Mauseth 1988). A subterranean shoot's sequestering of starch reflects the investment dedicated to the eventual production of the inflorescence. In addition, the copious starch is a likely attractant to herbiuores. Fbundant druse crystals in cortial cells of $\underline{B}$. hookeri may deter foraging animals as described in other plants (Franceschi and Horner 1980).

In the shoot of Conopholis americana, Percival (1931) observed that thick walled "fibers" formed in aggregations to the outside of the phloem and kylem of all three rings of vascular bundles. Primary phloem fibers in broomrape shoots also have been observed in 0robanche squamaria and encircling the vascular bundles of Orobanche hederae and Christisonia species. In the present study, fibers of primary origin were not present in either the phloem or kylem.

Brachysclereids (stone cells) were common in the pith and corten of $\underline{B}$. hookeri. Large sclereid clusters to the outside and inside of the vascular bundles were a consistent feature. 
Perciual (1931) also comments on the abundance of "thickwalled parenchyma", or sclereids, in the ground tissues of the pith, cortex, and between the three vascular rings of the broomrape $\underline{\underline{C}}$. americana. The function of the brachysclereids in B. hookeri may be two-fold. First, the lack of primary fibers and limited xylem does not provide much support to the shoot, thus support is augmented by the sclereids. Notwithstanding, the growth of a subterranean shoot would presumably not require significant supporting tissues because of external support from the surrounding soil. Sclereids may also prevent lateral crushing from soil expansion and contraction due to changes in hydration or temperature. Second, since the larger aggregations of brachysclereids were outside of the vascular tissues, they may play a role as an anti-herbiuore barrier. In the shoot of $\underline{B}$. hookeri, tangential sections of the inner corter showed that brachysclereids effectively form a discontinuous perforated cylinder of tissue, suggesting they function in support and protection.

The eustele is a typical vascular arrangement for the shoots of most dicotyledonous plants (Esau 1977; Mauseth 
1988; Metcalfe and Chalk 1958). Shoots of non-parasitic members in the Scrophulariaceae have a cylinder (ring) of vascular tissue, as do parasitic figworts such as Lathraea and Striga (Metcalfe and Chalk 1950). The broomrape Conopholis americana has an anomalous (uariant) form of growth represented by three rings of collateral bundles (Perciual

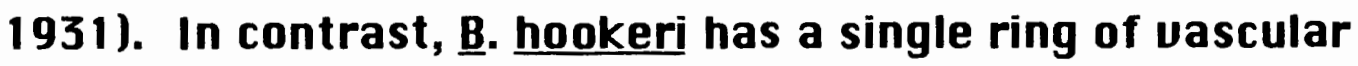
tissue and wide leaf gaps. This vascular arrangement is in agreement with the obseruations of other broomrapes. Boschniakia rossica (Gariliuk 1965), Epifagus virginiana (Cooke and Schively 1984; Walsh and Popovich 1977) and Orobanche hederae (Tate 1925) all have a single ring of vascular bundles with wide leaf gaps in their shoots. The further arrangement in B. hookeri of distinct vascular bundles along four fronts (quadrangular arrangement) characterizes the more advanced holoparasites of both the Scrophulariaceae and Orobanchaceae (Boeshore 1920; Metcalfe and Chalk 1950). A similar arrangement has been observed in the holoparasitic figwort Gerardia aphylla, and selected broomrapes species in Orobanche (Boeshore 1928) and Christisonia (Worsdell 1895). 
B. hookeri has an arrangement of uascular bundles that differ several centimeters above the tubercle from that at the interface of the tubercle and shoot. The quadrangular arrangement of vascular bundles becomes a narrow ring of twelve to fourteen eveniy spaced bundles at the interface. This arrangement of evenly spaces bundles is similar to the vascular organization in the aerial shoots of the broomrapes Epifagus virginiana (Cooke and Schively 1904) and Christisonia neilgherrica (Worsdell 1895). This 'ring' arrangement seems to be a characteristic found in aerial shoots, or the narrowed shoot at the tubercle interface, in some broomrapes.

The collateral vascular bundles of $\underline{B}$. hookeri are reminiscent of those in nonparasitic dicotyledons (Esau 1977; Mauseth 1988). In B. hookeri the shoot hylem is composed of abundant parenchyma and limited numbers of vessel members. All metakylem vessel members had simple perforations. Kuijt and Toth (1985) noted that vessel members at the haustorial interface had simple perforations. Uessel members with simple perforations appear to be a consistent feature in members of the Orobanchaceae (Metcalfe and Chalk 1950). Uessel members 
have been reported in the broomrapes Orobanche hedera (Tate 1925) and Conopholis americana (Perciual 1931), however in the latter perforations were, at times, noted as failing to form. It is noteworthy in B. hookeri, as in other broomrapes, that relatively few vessels are present in the shoot. Uessels occur singularly and in small radial or tangential groups. Lateral wall pits in $\underline{B}$. hookeri were nearly circular to elongated (laterallywidened). Similar pitting in the monogeneric parasitic family, Misodendraceae, have been observed (Carlquist 1985).

Carlquist (1985) found that elongated pit apertures were associated with species having more succulent shoots containing abundant axial parenchyma. Carlquist (1985) proposed that elongated pit apertures maintain conductance following changes in the volume of the stem. In B. hookeri's succulent shoot, elongated pitting may also provide the same function.

Due to the problems associated with the study of phloem, few workers have convincingly demonstrated the presence of sieve tube members in parasitic members of Scrophulariaceae and Orobanchaceae (Dörr and Kollman 1975; Dörr, Kollman and 
Uisser 1979; Kuijt and Dobbins 1971; Walsh and Popouich 1977; Worsdell 1895). The accepted evidence of sieve tube members is sieve plates containing pores. Sieve pores are characterized by the deposition of callose. Fluorescence microscopy and aniline blue staining revealed that $\underline{B}$. hookeri has an abundance of sieve tube members with simple sieve plates and numerous lateral pores in the phloem. Kuijt and Toth (1985) did not find phloem at the host-parasite interface, but predicted its presence in the shoot. This study confirms their prediction. Sieve tube members appeared to form regular series separated by uniseriate files of phloem parenchyma. Radial files of sieve tube members were also noted to occur in Christisonia (Worsdell 1895). Radial files of phloem parenchyma were also seen in Conopholis americana by Percival (1931) who interpreted them as secondary phloem. However, no "sieve tubes" with sieve plates were observed by Percival (1931), leading him to the conclude that they had been eliminated in this aduanced parasite. Percival's (1931) observation stands in conflict with Boeshore (1928), who concluded that from the hemiparasitic figworts through the holoparasitic broomrapes 
the conducting phloem becomes more significant in the transport of material within the root parasite. Boeshore's view is supported by the presence of sieve tube members in $\underline{B}$. hookeri. Reekamination by modern methods for the presence or absence of sieve tube members in Conopholis americana is warranted.

Sieve tube members in $\underline{B}$. hookeri usually had a granular red-stained material accumulated at the sieve plate. This material, interpreted to be P-protein plugs, or slime, is common to most flowering plants (Esau 1977; Mauseth 1988). Of interest, the ultrastructural study of Walsh and Popouich (1977) found that the sieve tube members in the aerial stem of the broomrape Epifagus virginiana lacked P-protein, a condition novel to a holoparasite. Further study, particularly at the ultrastructural level, is needed to confirm the presence and significance of $P$-protein in the sieve elements of holoparasitic angiosperms.

A prominent feature of the epidermis of $\underline{B}$. hookeri was the presence of stomata on the stem and leaf. The occurrence of stomata, and hydathodes, is common among members of the 
Orobanchaceae (Kuijt 1969; Metcalfe and Chalk 1950; Solereder 1908). Stomata were frequently encountered along the stem aboue the arillary buds in $\underline{B}$. hookeri. While stomata on the stem near the tubercle interface appeared to be functional, stomata several centimeters above the tubercle had guard cells with thickened, cuticularized walls. The thickened walls make it highly unlikely that these modified stomata are functional. Similar modified stomata have been observed in Christisonia neilgherrica (Worsdell 1895), while vestigial stomata with cuticularized crypts have been observed in Conopholis americana (Percival 1931).

A parados involving stomatal function in the holoparasites is noted by Kuijt (1969). Stomata in aduanced holoparasites are few, vestigial, or lacking, yet holoparasites are presumed they obtain water from their hosts by transpiration through stomata. Alternatively, subterranean shoots of parasites such as $\underline{B}$. hookeri may rely primarily on host root pressure to acquire water and nutrients. In the

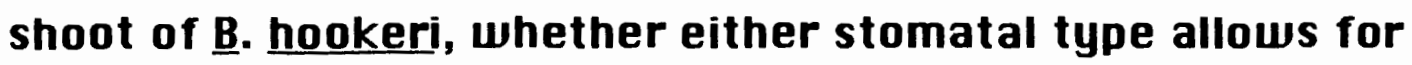
significant transpiration to occur, or whether they act like 
hydathodes, was not determined by this study. However, it was noted that in early morning observations of the aerial inflorescences liquid water was present in many leaf axils and on the abakial leaf blades. This observation supports the view that root pressure is operative in $\underline{B}$. hookeri, and that modified stomata are present to act as hydathodes.

Subterranean shoots were found to have two types of asillary buds. Floral buds developed near the soil surface and were easily identifiable by the presence of a lobed calyx and two slender bractlets. Buds several centimeters below the soil surface were vegetative. This vegetative character was confirmed by the collection of specimens that had flowered, or had received damage to the apical meristem, and manifested vegetative bud activation. $\mathrm{A}$ vegetative bud gave rise to a branch shoot that, like the original shoot, successfully terminated in an inflorescence. Branch shoots in $\underline{B}$. hookeri have also been observed by 0Isen and 0Isen (1981) who described them as "secondary stems."

The consequence of the shoot's maintenance following its flowering, and additional lateral shoot activation, was the 
development of secondary vascular tissues. Considerable secondary xylem and phloem were produced from divisions of the fascicular cambia. Interfascicular parenchyma elongated radially and divided anticlinally, but were not organized into a continuous interfascicular cambial zone. Solereder (1988) noted that secondary growth in thickness in the vascular bundles was found among seueral genera in the Orobanchaceae. And Percival (1931) noted that the vascular bundies at the stem and tubercle interface of Conopholis americana had a larger volume of secondary xylem and phloem than at points higher up the stem.

Several workers have recognized a corky surface on the tubercle of $\underline{B}$. hookeri (Kuijt and Toth 1985; DIsen and Olsen 1981). Cork, the product of a cork cambium, was characterized by Olsen and Disen (1981) on the $\underline{B}$. hookeri's tubercle. In my study, the production of a cork-like layer was observed in the maintained shoots that support branch shoots. This cork-like layer was most developed at the shoot base and made the distinction between shoot and tubercle difficult. The continuity of a corky covered shoot and tubercle is also a characteristic 
of Conopholis americana (Boeshore 1920; Kuijt 1969; Percival

1931). However, this study found no evidence of a cork

cambium in the subterranean shoot or tubercle. Disordered cell

division and evidence of cuticularization in the outer corter

gave rise to this protective cork-like layer. This is more

consistent as evidence of a tissue called cuticular epithelium, also seen in the aerial shoot of the mistletoe, Phoradendron flavescens (Calvin 1970). Further investigation of this outer protective layer should be conducted for other broomrapes.

Collateral vascular bundles in the scales leaves of $\underline{B}$.

hookeri were of relatively uniform size and limited in number. Mesophyll in the scale leaves was homogeneous. According to Metcalfe and Chalk (1950) and Solereder (1908), homogeneous mesophyll is a consistent characteristic for members of the Orobanchaceae. Certainly, the reduction of nonphotosynthetic leaves to scales is a consistent trend (Boeshore 1925; Kuijt 1969; Metcalfe and Chalk 1950) in the advancement to the holoparasitic mode of nutrition.

A black fly, Pegomya hyperparasitica, has been found to lay its eggs in the aerial inflorescence of $\underline{B}$. hookeri (Deyrup 
1989). The developing laruae were described by Deyrup (1989) as having a destructive impact limited to the seed capsules and inflorescence axis. In the preparation of shoots for this study, numerous specimens of $\underline{B}$. hookeri were encountered with laruae, presumably of $\underline{P}$. hyperparasitica. The larvae, or hollowings from their feeding on the shoot, were restricted mainly to the corter. Laruae were found not only in the inflorescence, but also deep in the subterranean shoots. In one instance, a living larva was found at the interface of the shoot and tubercle. Insects that parasitize broomrapes are not uncommon. Phytomyza orobanchia, a fly that also feeds on the fruits and stems, has been investigated as a biological control of Orobanche (Linke et al. 1990; Sauerborn 1991).

Fungal hyphae were found occasionally on the epidermis and within wound ares of the $\underline{B}$. hookeri. No observations suggested that a fungus was inducing injury or in a symbiosis. Worsdell (1895) described a fungus at the haustorial interface of Christisonia as damaging the parasite by inuading the intercellular spaces and cortical cells. Orobanche crenata and o. minor have been found to be associated with as many as 
sikteen different species of fungi (Linke et al. 1992). Parasitic fungi has been reported in Orobanche (Sauerborn 1991; Linke et al. 1992), and investigated as biological controls. The subterranean habit of root parasites lead to an unavoidable interaction with soil fungi.

Boeshore (1920) and Kuijt (1969) regard annuals such as Orobanche as less aduanced than the perennial holoparasites of the Orobanchaceae. Boeshore $(1920)$ also concluded that hostspecificity is an advanced characters in the broomrapes. Carlquist (1988) says "hgreement is general that the 'normal' cambium is ancestral in dicotyledons...," and that variant or “anomalous" growth is an aduanced characteristic in plants. The perennial habit, restricted host-specificity, and anomalous vasculature of Conopholis americana represents the most "degraded," or parasitically aduanced, of the broomrapes. Results of this study suggest that Boschniakia hookeri may be less specialized than conopholis americana because it has less host-specificity and lacks a variant form of growth.

Continuing investigations of the role of stomata, formation of a protective cork-like layer, vascular tissue 
composition and function in root parasites, such as Boschniakia hookeri, are indispensable to our understanding of their unique life-style, direct interaction with animals and fungi, and ecological significance. 


\section{LITERATURE CITED}

Beck v. Mannagetta, G. (1930). Orobanchaceae, in A. Engler, Das Pflanzenreich. 96: 1-348.

Boeshore, I. (1920). The morphological continuity of Scrophulariaceae and Orobanchaceae. Contributions from the Botanical Laboratory of the University of Pennsylvania. 5: 139-177.

Caluin, C. L. (1970) Anatomy of the aerial epidermis of the mistletoe, Phoradendron flavescens. Botanical Gazette. 131:62-70.

Carlquist, S. (1985) Wood and stem anatomy of Misodendraceae: Systematic and ecological conclusions. Brittonia. 37: 1, 58-75.

Carlquist, S. (1988) Comparative wood anatomy. SpringerUerlag, New York.

Chatin, G. A. (1856). Anat. comp. d. veget., Pl. paras. pp. 42130. Translation in H. Solereder's (1908) "Systematic anatomy of the dicotyledons."

Cooke, E., and Schively, A. (1904). Observation on the structure and development of Epifagus virginiana. Contributions from the Botanical Laboratory of the University of Pennsyluania. 2: 352-398.

Currier, H. and Strugger, S. (1955). Aniline blue and fluorescence microscopy of callose on bulb scales of fllium cepa L. Protoplasma. 45: 552-559. 
Deyrup, M. (1989). A new species of Pegomya (Diptera:

Anthomyiidae) attacking Boschniakia (Orobanchaceae). PanPacific Entomologist. 65: 1, 38-42.

Dörr, I. and Koliman, R. (1975). Structural features of parasitism of Orobanche. II. The differentiation of assimilate conducting elements within the haustorium. Protoplasma. 83: 185-199.

Dörr, I., Visser, J., and Kollman R. (1979). On the parasitism of Alectra vogelii Benth. (Scrophulariaceae). III. The occurrence of phloem between host and parasite. Z. Pflanzenphysiol. Bd., 94: 427-439.

Esau, K. (1977). Anatomy of seed plants (2nd ed.). John Wiley \& Sons, New York.

Eschrich, W., and Currier, H. (1964). Identification of callose by its diachrome and fluorochrome reactions. Stain Technology. 39: 5, 303-307.

Franceschi, U. and Horner, H. (1980). Calcium oxalate crystals in plants. Botanical Review. 46: 4, 361-427.

Gariliuk, S. (1965). A contribution to the biology of the parasitic plant Boschniakia rossica (Cham. et Schlecht) B. Fedtsch. Bot. Zhurn. 50: 523-528.

Gifford, E., and Foster, A. (1989). Morphology and evolution of vascular plants. W. H. Freeman and Company. New York.

Gilkey, H. M. (1980). Handbook of northwest plants. Oregon State University Bookstore, Inc. Corvallis, Oregon.

Gilkey, H. M. (1945). Northwestern American Plants. Boschniakia in Western United States. Oregon State Monographs. Bot. 9: 7-15. 
Hitchcock, C., Cronquist, A., Ownbey, M., and Thompson, J. (1998). Wascular plants of the Pacific Northwest, Part IV: Ericaceae through Campanulaceae. (6th ed.). University of Washington Press, Seattle.

Hultén, E. (1968). Flora of Alaska and neighboring territories. manual of the vascular plants. Stanford University Press, Stanford, California.

Jensen, Ш. (1962). Botanical Histochemistry. Ш. H. Freeman and Company, New York.

Kuijt, J. (1969). The Biology of Parasitic Flowering Plants. Uniuersity of California Press, Berkeley.

Kuijt, J., and Dobbins, D. (1971). Phloem in the haustorium of Castille ja (Scrophulariaceae). Canadian Journal of Botany. 49: $1735-1736$.

Kuijt, J., and Toth, R. (1985). Structure of the host-parasite interface of Boschniakia hookeri Walpers (Orobanchaceae). Acta Bot. Neerl. 34: 3, 257-270.

Linke, K., Scheibel, C., Sasena, M., and Sauerborn, J. (1992) Fungi occurring on 0robanche spp. and their preliminary evaluation for 0robanche control. Iropical Pest Management. 38: 2, 127-130.

Linke, K., Uorlaender, C., and Sasena, M. (1990). Occurrence and impact of Phytomyza orobanchia (Diptera Agromyzidae) on Orobanche crenata (Orobanchaceae) in Syria. Entomophaga. 35: 4, 633-640.

Mauseth, J. (1988). Plant Anatomy. The Benjamin/Cummings Publishing Company, Inc., Menlo Park, California.

Metcalfe, C. and Chalk, L. (1958). Anatomy of the dicotyledons Dol. I-II. The Clarendon Press, Orford. 
Munz, P. A. (1963). A California Flora. University of California Press, Berkeley and Los Angeles.

Murai, F. and Tagawa, M. (1980) The absolute configuration of boschnaloside and the chemical conversion of genipin into boschnaloside. Chem. Pharm. Bull. 28: 6, 1730-1735.

Musselman, L. (1975). The structure and development of the haustorium in parasitic Scrophulariaceae. Bot. J. Linn. Soc. 70: 183-212.

Olsen, S., and Olsen, I. (1980). The seed of Boschniakia hookeri (Orobanchaceae). Bot. Tidsskr. 75: 159-172.

Olsen, S., and Olsen, I. (1981). Germination and development of the soma in Boschniakia hookeri (Orobanchaceae). Nordic J. Botany. 1: 246-259.

Olsen, S. and Deyrup-0Isen, I. (June 1979). Growth of host root establishes contact with parasitic angiosperm Boschniakia hookeri. Nature. 279: 635-636.

Olsen, S., Deyrup, S., and Deyrup-0Isen, I. (1989). Biology of a Pegomya fly (Diptera: Anthomyiidae) attacking the parasitic plant Boschniakia (Orobanchaceae). Pan-Pacific Entomologist. 65: 1, 43-49.

Peck, M. A. (1961). A manual of the higher plants of Oregon. Oregon State University Press, Portland, Oregon.

Percival, W. C. (1931). The parasitism of Conopholis americana on Quercus borealis. American Journal of Botany.

18: 10, 817-837.

Polunin, O., and Stainton, A. (1984). Flowers of the Himalaya. Oxford University Press, 0xford. 
Sauerborn, J. (1991). Parasitic flowering plants: Ecology and Management (Barbara Müller, Trans.). Derlag Josef Margraf, Scientific Books, Weikersheim, Germany.

Sisido, K., Kageyama, T., Mera, H., and Utimoto, K. (1967) Synthesis of boschnia-lactone and the stereoisomers. Ietrahedron Letters. 16: 1553-1555.

Solereder, H. (1908). Systematic anatomy of the dicotyledons: $\mathrm{A}$ handbook for laboratories of pure and applied botany. (Translation by L. A. Boodle and F. E. Fritsch). The Clarendon Press, Drford.

Tate, P. (1925). On the anatomy of Orobanche hederae Duby, and its attachment to the host. The New Phytologist. 24: 234-293.

Tiagi, B. (1963). Studies in the Family Drobanchaceae. IV. Embryology of Boschniakia himalaica Hook. and B. tuberosa (Hook.) Jepson, with remarks on the evolution of the family. Botaniska Notiser. 116: 1, 81-93.

Tsuda, T., Sugaya, A., Liu, Y., Kotoh, K., Tanaka, H., Kawazura, H., Sugaya, E., Kusai, M., and Kohno, M. (1994) Radical scavenger effect of Boschniakia rossica. Journal of Ethnopharmacology. 41: 85-90.

Tusda, T., Liu, Y., Sugaya A., Katoh, K., Hori, K., Tanaka, S., Nomura, M., and Sugaya, E. (1994). Reinforcement effects of Boschniakia rossica on discrimination learning in cholinergic lesions of rats. Journal of Ethnopharmacology. 44: 67-71.

Walsh, M., and Popouich, T. (1977). Some ultrastructural aspects of metaphloem sieve elements in the aerial stem of the holoparasitic angiosperm Epifagus virginiana (Orobanchaceae). American Journal Botany. 63: 3, 326-336. 
Weber, H. C. (1987). Euolution of the haustoria to a primary haustorium in the parasitic Scrophulariaceae/Orobanchaceae. Plant Systematic Evolution. 156: 127-131.

Weidemann, A., Dennis, L., and Smith, F. (1969). Plants of the Oregon coastal dunes. OSU Bookstore, Corvallis, Oregon.

Worsdell, W. (1895). On the comparative anatomy of certain species of the genus Christisonia. Annals of Botany. 9: 103136. 